\title{
Feed intake, body weight changes and haematology of West African dwarf goats fed dietary levels of Moringa oleifera leaf meal
}

\author{
Peter-Damian Chukwunomso JIWUBA ${ }^{1 *}$, Francis Okechukwu AHAMEFULE², Okechukwu Samuel OKECHUKWU', \\ Kingsley IKWUNZE ${ }^{2}$ \\ ${ }^{1}$ Federal College of Agriculture, P.M.B.7008, Ishiagu, Ebonyi State, Nigeria \\ ${ }^{2}$ Michael Okpara University of Agriculture, Umudike, Abia State, Nigeria
}

\begin{abstract}
A 90-day study was carried out with 36 West African Dwarf goats to determine the effect of Moringa oleifera leaf meal (MOLM) on feed intake, body weight changes and haematology of WAD does. Four diets were formulated such that diets $\mathrm{T} 1, \mathrm{~T} 2, \mathrm{~T} 3$ and T4 contained MOLM at $0 \%, 5 \%, 10 \%$ and $15 \%$, respectively. The diets were offered to the goats, which were randomly divided into four groups of nine goats each in a completely randomized design. Average daily feed intake (ADFI), average daily weight gain (ADWG), feed conversion ratio (FCR) and heamatology of the animals were determined and statistically analyzed. Results showed that ADFI, ADWG differed significantly $(\mathrm{P}<0.05)$ with T4 goats having better values. FCR was however best for does fed T4 diet. $\mathrm{PCV}, \mathrm{RBC}, \mathrm{MCV}$ and $\mathrm{WBC}$ differed $(\mathrm{P}<0.05)$ significantly among the treatments. Packed cell volume $(29.50-32.75 \%)$ was improved $(\mathrm{p}<0.05)$ by MOLM supplementation at $15 \%$ inclusion level. White blood cell counts for goats in treatment groups were significantly $(\mathrm{p}<0.05)$ higher and better than the control. Incorporation of 15\% MOLM in diets of WAD does enhanced their performance and heamatological profile. Moringa oleifera leaf meal supplementation level at 15\% was recommended for optimum West African Dwarf goat production.
\end{abstract}

Key words: body weight changes, haematology, Moringa oleifera, leaf meal, west african dwarf goat, alternative feedstuff

\section{INTRODUCTION}

In the Tropics, goats suffer scarcity of feed especially during the dry season when the natural pastures and postharvest crop residues are depleted in most nutrients and can barely sustain their maintenance. In Nigeria, Ahamefule and Elendu (2010) identified feed shortage as a major constraint to West African Dwarf (WAD) goat production. This could be from the fact that the extensive system of goat production in Nigeria encourages the raising of WAD goats on range.

During the dry season, trees and shrubs provide green fodder, leaves, flowers, and fruits often rich in protein, vitamins and minerals (Agboola, 2012). Trees such as Moringa oleifera provide useful forage in the form of leaves and seeds and can be used to supplement poor quality and low protein roughage. The importance of multipurpose plants as source of protein and energy to ruminants particularly during the dry season of the year can never be over emphasized. However, these plants cannot constitute a complete feed when fed alone due to nutrient imbalance; thus the need to incorporate them to form supplement.

Moringa oleifera is a multipurpose evergreen tree that has both medicinal and nutritional properties and considerable fodder yield during the wet and dry seasons. Nouala et al. (2006) reported that Moringa oleifera offers a good alternative source of feed during the dry seasons. M. oleifera is a wellknown tree in Asia and West Africa especially in semi-arid zone where it is often cultivated as a live fence and barely utilized for any other purpose. Leaves of the tree are noted for high crude protein, energy and appreciable levels of carotene, ascorbic acid, iron, methionine and cystine with negligible amounts of tannins (Makkar and Becker, 1996). However, the value of the foliage and its benefits as a high quality supplement to low-quality roughages in ruminant feeding systems during the dry season have not been fully known nor widely exploited (Fadiyimu et al., 2011). 
Therefore, to the high and untapped nutrient profile of Moringa oleifera as a dry season supplements for ruminants, the present study investigated the effect of various levels of Moringa oleifera leaf meal supplementation on feed intake, body weight changes and heamatology of WAD does. A strong justification for carrying out feed intake, body weight changes haematological evaluation is the fact that Moringa oleifera contains antinutritional factors like tannin and phytate which can possibly lead to poor palatability and precipitation of anaemia and thus compromise the health status of the animal.

\section{MATERIALS AND METHODS}

\section{Location of the Experiment}

The experiment was conducted at the Sheep and Goat unit of the Teaching and Research farm of Michael Okpara University of Agriculture, Umudike. Umudike is in Abia State, Nigeria, located at latitude 050281 North and longitude 07 o311 East and lies 122 meters above sea level. Umudike lies within the tropical rainforest zone, characterized by average annual rainfall of $2,177 \mathrm{~mm}$ in $148-155$ rain days. Average ambient temperature was $25.5 \mathrm{oC}$ with minimum and maximum temperatures of $22 \mathrm{oC}$ and $29 \mathrm{oC}$ respectively. Relative humidity ranged from $76-87 \%$.

\section{Sources and Processing of Experimental Material}

Fresh Moringa oleifera leaves used for the trial were obtained from Ihitte Uboma and Obowo Local government areas, both in Imo State, Nigeria. Moringa oleifera leaves were subsequently air-dried to about $10 \%$ moisture content before milling and used at different levels in the formulation of diets containing Moringa oleifera leaf meal (MOLM).

\section{Experimental Diets}

Experimental diets designated as T1, T2, T3 and T4 were formulated from cassava peel, brewers dried grain, palm kernel meal, maize offal, Moringa oleifera leaf meal, bone meal and salt. Diet T1 served as a positive control and contained $0 \%$ of MOLM. Diets T2, T3 and T4 contain 5\%, 10\% and 15\% inclusion levels of Moringa oleifera leaf meal respectively as presented in Table I.

\section{Management of Experimental Animals}

Thirty six (36) West African Dwarf does of about 10 12 months of age and averaging $8.43 \mathrm{~kg}$ were purchased and quarantined for 21 days and subsequently fed for a preliminary period of 21 days. The ration fed was the control diet in addition to fresh Panicum maximum for acclimatization. This was done to build up each animal's appetite for concentrate diet. Prior to the trial, the animals were dewormed and sprayed against external parasites.

Table 1: Gross composition of the experimental diets ratio

\begin{tabular}{|l|c|c|c|c|}
\hline & \multicolumn{4}{|c|}{ Diets (\%) } \\
\hline Ingredients & T1 & T2 & T3 & T4 \\
\hline Maize offal & 30 & 30 & 30 & 30 \\
\hline Cassava peel meal & 20 & 20 & 20 & 20 \\
\hline Palm kernel cake (PKC) & 22 & 22 & 22 & 22 \\
\hline Brewer's dried grain (BDG) & 25 & 20 & 15 & 10 \\
\hline $\begin{array}{l}\text { Moringa oleifera leaf meal } \\
\text { (MOLM) }\end{array}$ & 0 & 5 & 10 & 15 \\
\hline Bone meal & 2 & 2 & 2 & 2 \\
\hline Salt & 1 & 1 & 1 & 1 \\
\hline Total & $\mathbf{1 0 0}$ & $\mathbf{1 0 0}$ & $\mathbf{1 0 0}$ & $\mathbf{1 0 0}$ \\
\hline
\end{tabular}

\section{Growth Trial}

After the preliminary feeding period, the thirty six WAD goats were randomly divided into four groups of nine animals each with three goats constituting a replicate. The groups were randomly assigned the 4 treatment diets (T1, T2, T3, and T4) in a Completely Randomized Design (CRD). The animals were housed individually in well ventilated cement floored pens equipped with feeders and drinkers. Each animal received designated treatment diet in the morning for 90 days. Feed offered was based on 3\% body weight per day; the animals in addition were fed $2 \mathrm{~kg}$ fresh Panicum maximum later in the day. Regular access to fresh drinking water was made available. Feed offered and refusals were recorded on a daily basis. Initial weights of the animals were taken at the beginning of the trial and weekly subsequently.

\section{Haematological Studies}

Blood samples $(5 \mathrm{ml})$ were drawn from each animal on days 1, 30, 60 and 90 of the study. The goats were bled through the jugular vein and were used for haematological determinations. The blood samples were collected from each blood sample in labelled sterile universal bottle containing $1.0 \mathrm{mg} / \mathrm{ml}$ ethyldiamine tetracetic acid (EDTA) and used for haematological analysis. The $\mathrm{MCV}, \mathrm{MCH}$ and $\mathrm{MCHC}$ were calculated from $\mathrm{PCV}, \mathrm{Hb}$ and $\mathrm{RBC}$ using the formulae below:

$$
\begin{aligned}
& \operatorname{MCV}(f l)=\frac{P C V}{R B C \text { count }} \times 10 \\
& \operatorname{MCH}(g / d)=\frac{\mathrm{Hb}}{\mathrm{RBC} \text { count }} \times 10 \\
& \operatorname{MCHC~}(\%)=\frac{\mathrm{Hb}}{\mathrm{PCV}} \times 100
\end{aligned}
$$




\section{Analytical Procedure}

All feed samples were analysed for proximate compositions using the method of AOAC (2000). Gross energy was determined according to Nehring and Haelein (1973).

\section{Statistical Analysis}

The data collected in this study were subjected to Analysis of variance (ANOVA) appropriate for Completely Randomized Design (Steel and Torrie, 1980) using SPSS computer software package. Differences between treatment means were separated using Duncan Multiple Range Test (Duncan, 1955).

\section{RESULTS}

The proximate composition of the experimental diets, Moringa oleifera leaf meal and Panicum maximum used in this study are presented in Table II. The analyses revealed the presence of dry matter, crude protein, crude fibre, ether extract, ash and energy. Proximate analysis of Moringa oleifera leaf meal revealed the presence of dry matter $(87.90 \%)$ crude protein (23.24\%), crude fibre (15.16\%), ether extract (4.15\%), ash (6.21\%) nitrogen free extract (39.14\%) and energy $(4.03 \mathrm{MJ} / \mathrm{g})$ The proximate analysis also revealed the presence of dry matter, crude protein, crude fibre, ether extract, ash and nitrogen free extract for the experimental diets. The dry matter content of the Moringa oleifera leaf meal (MOLM) containing diets (T2, T3 and T4) compared favourably with the control diet (T1). Ether extract, gross energy and nitrogen free extract values did not show any consistent trend across the treatment diets. Table III shows the feed intake and body weight of WAD does fed diets containing Moringa oleifera leaf meal. The diets influenced positive weight changes $(\mathrm{P}<0.05)$ among the experimental groups. Average daily feed intake (ADFI) differed significantly $(\mathrm{P}<0.05)$ among the treatment groups. Value for the animals fed control diet (T1) compared $(\mathrm{P}>0.05)$ with those of $\mathrm{T} 2$ and $\mathrm{T} 3$, but however differed $(\mathrm{P}<0.05)$ significantly from that group fed $\mathrm{T} 4$ diet. Total feed intake, dry matter intake as percentage of body weight (DMI\%BWT) for concentrate, DMI \%BWT for forage and total dry matter intake, however were not influenced $(\mathrm{P}>0.05)$ by the treatment diets; the values increased from the control diet $\mathrm{T} 1$ to $\mathrm{T} 4$. Average daily dry matter intake was significantly $(\mathrm{P}<0.05)$ affected by the treatment diets, with $\mathrm{T} 1$ having the lowest value of $395.14 \mathrm{~g}$ as against $411.47,442.82$ and $448.69 \mathrm{~g}$ for T2, T3 and T4 respectively. Goats that received T4 diet had the highest average daily weight gain $(46.00 \mathrm{~g} / \mathrm{d})$ in comparison to T1 $(32.22 \mathrm{~g} / \mathrm{d}), \mathrm{T} 2(35.00 \mathrm{~g} / \mathrm{d})$ and T3 $(44.66$ g/d) respectively. Treatments had no significant $(\mathrm{P}>0.05)$ effect on final weight, however values obtained for total weight gain and average daily weight gain were significantly $(\mathrm{P}<0.05)$ affected by treatments diets. The respective values for T3 $(4.02 \mathrm{~kg} ; 44.66 \mathrm{~g})$ and T4 $(4.14 \mathrm{~kg} ; 46.00 \mathrm{~g})$ were similar $(\mathrm{P}>0.05)$ but however higher $(\mathrm{P}<0.05)$ than the values obtained for T1 (2.90kg; 32.22g) and T2 (3.15kg; $35.00 \mathrm{~g})$; these latter values did not differ $(\mathrm{P}>0.05)$ from each other. The feed conversion ratio $(\mathrm{FCR})$ differed $(\mathrm{P}<0.05)$ among treatment groups. T1 and T2 values were significantly $(\mathrm{p}<0.05)$ higher than T3 and T4; even though there was no statistical $(\mathrm{p}>0.05)$ difference between the latter, T4 had the least FCR indicating a better feed conversion ratio. The haematological profile of WAD goat fed Moringa oleifera leaf meal containing diets are presented in Table IV. Packed cell volume (PCV) for the control diet differed $(\mathrm{P}<0.05)$ significantly from the value of $\mathrm{T} 4$, but not from T2 or T3 $(\mathrm{P}>0.05)$. The haemoglobin $(\mathrm{Hb})$ $(\mathrm{g} / \mathrm{dl})$ values obtained in this study showed no significant $(\mathrm{P}>0.05)$ differences among dietary groups. The $\mathrm{Hb}$ values tended to increase with the increasing levels of the test ingredient. The values obtained, were also within the normal range of $9.98-10.88 \mathrm{~g} / \mathrm{dl}$. Haemoglobin values reported for the goats fed T3 and T4 diets were relatively high; this is an advantage as these diets seemed to be capable of supporting high oxygen carrying capacity of blood in these animals. The red blood cells $(\mathrm{RBC})$ were significantly affected $(\mathrm{P}<0.05)$ by treatment diets in the present study. The $\mathrm{T} 4$ value did not differ $(P>0.05)$ significantly with control diet $\mathrm{T} 1$, but however differed $(\mathrm{P}<0.05)$ significantly from the values of

Table 2: Proximate compositions of the experimental diets, Moringa oleifera leaf meal and Panicum maximum (\% DM basis)

\begin{tabular}{|l|c|c|c|c|c|c|}
\hline Dietary levels & T1 & T2 & T3 & T4 & MOLM & PM \\
\hline Parameters & 88.15 & 90.47 & 90.92 & 90.61 & 87.90 & 34.00 \\
\hline Dry matter (DM) & 17.07 & 18.79 & 19.38 & 20.20 & 23.24 & 7.21 \\
\hline Crude protein & 16.83 & 17.93 & 18.21 & 18.63 & 15.16 & 19.16 \\
\hline Crude fibre & 4.19 & 3.76 & 3.25 & 3.56 & 4.15 & 1.92 \\
\hline Esther extract & 16.22 & 16.56 & 16.94 & 17.02 & 6.21 & 1.70 \\
\hline Ash & 33.84 & 33.43 & 32.71 & 31.20 & 39.14 & 4.01 \\
\hline Nitrogen free extract & 3.54 & 3.64 & 3.61 & 3.64 & 4.03 & 1.67 \\
\hline Gross energy (Kcal/g) & &
\end{tabular}

MOLM = Moringa oleifera leaf meal

$\mathrm{PM}=\quad$ Panicum maximum 
Table 3: Feed intake and body weight changes of WAD does fed diets containing Moringa oleifera leaf meal

\begin{tabular}{|c|c|c|c|c|c|}
\hline Parameter & T1 & T2 & T3 & T4 & SEM \\
\hline Initial weight (kg) & 8.33 & 8.47 & 8.40 & 8.53 & 0.14 \\
\hline Final weight $(\mathrm{kg})$ & 11.23 & 11.62 & 12.42 & 12.67 & 0.28 \\
\hline Total weight gain $(\mathrm{kg})$ & $2.90^{\mathrm{b}}$ & $3.15^{\mathrm{b}}$ & $4.02^{\mathrm{a}}$ & $4.14^{\mathrm{a}}$ & 0.20 \\
\hline Av. daily weight gain (g/day) & $32.22^{\mathrm{b}}$ & $35.00^{\mathrm{b}}$ & $44.66^{\mathrm{a}}$ & $46.00^{\mathrm{a}}$ & 2.22 \\
\hline Average daily feed Intake (g/day) & $448.26^{\mathrm{b}}$ & $454.81^{\mathrm{ab}}$ & $487.04^{\mathrm{ab}}$ & $495.19^{\mathrm{a}}$ & 8.05 \\
\hline Total feed intake $(\mathrm{kg})$ & 40.34 & 40.93 & 43.83 & 44.57 & 1.36 \\
\hline Average daily DMI (g/day) & $395.14^{\mathrm{b}}$ & $411.47^{\mathrm{ab}}$ & $442.82^{\mathrm{a}}$ & $448.69^{\mathrm{a}}$ & 8.11 \\
\hline DMI \% BWT Concentrate (\%) & 2.60 & 2.63 & 2.70 & 2.69 & 0.03 \\
\hline DMI \% BWT Forage (\%) & 0.69 & 0.71 & 0.72 & 0.73 & 0.05 \\
\hline Total DM intake \%BWT (\%) & 3.29 & 3.34 & 3.42 & 3.42 & 0.05 \\
\hline Feed conversion ratio & $13.90^{\mathrm{a}}$ & $12.99^{\mathrm{a}}$ & $10.90^{\mathrm{b}}$ & $10.77^{\mathrm{b}}$ & 0.48 \\
\hline
\end{tabular}

${ }^{\mathrm{a}, \mathrm{b}}$ means on the same row with different superscripts are significantly different at $\mathrm{p}<0.05$ )

DMI\% BWT Concentrate $=$ dry matter intake as percentage of body weight for concentrate

DMI\%BWT Forage = dry matter intake as percentage of body weight for forage

Table 4: Haematological profile of WAD does fed diets containing Moringaoleifera leaf meal

\begin{tabular}{|l|c|c|c|c|c|}
\hline & & \multicolumn{2}{|c|}{ Diets } & & \\
\hline Parameters & T1 & T2 & T3 & SEM \\
\hline Packed cell volume (\%) & $29.50^{\mathrm{b}}$ & $31.00^{\mathrm{ab}}$ & $32.12^{\mathrm{ab}}$ & $32.75^{\mathrm{a}}$ & 0.53 \\
\hline Haemoglobin $(\mathrm{g} / \mathrm{dl})$ & 9.98 & 10.49 & 10.70 & 10.88 & 0.17 \\
\hline Red blood cell $\left(\mathrm{x} 10^{6} / \mu \mathrm{l}\right)$ & $10.93^{\mathrm{ab}}$ & $10.60^{\mathrm{b}}$ & $10.70^{\mathrm{b}}$ & $11.45^{\mathrm{a}}$ & 0.11 \\
\hline Mean corpuscular volume (fl) & $27.02^{\mathrm{b}}$ & $29.24^{\mathrm{ab}}$ & $30.03^{\mathrm{a}}$ & $28.61^{\mathrm{ab}}$ & 0.45 \\
\hline MCHC (\%) & 33.89 & 33.82 & 33.31 & 34.06 & 0.45 \\
\hline Mean corpuscular haemoglobin $(\mathrm{g} / \mathrm{d})$ & 9.14 & 9.90 & 9.82 & 9.51 & 0.17 \\
\hline White blood cell $\left(\mathrm{x} 10^{3} / \mu \mathrm{l}\right)$ & $10.38^{\mathrm{d}}$ & $11.63^{\mathrm{c}}$ & $13.60^{\mathrm{b}}$ & $14.70^{\mathrm{a}}$ & 0.45 \\
\hline Lymphocyte $\%)$ & 53.50 & 57.13 & 59.50 & 61.13 & 1.53 \\
\hline Neutrophil $(\%)$ & 42.78 & 40.88 & 38.98 & 38.14 & 1.35 \\
\hline Eosinophil $\%)$ & 0.75 & 0.50 & 0.25 & 1.00 & 0.18 \\
\hline
\end{tabular}

${ }^{a-d}$ means on the same row with different superscripts are significantly different at $(p<0.05)$

$\mathrm{MCHC}=$ Mean corpuscular haemoglobin concentration

T2 and T3. Mean corpuscular volume (MCV) in goats fed the various treatment diets differed significantly $(\mathrm{P}<0.05)$, however Mean corpuscular haemoglobin $(\mathrm{MCH})$ and the Mean corpuscular haemoglobin concentration $(\mathrm{MCHC})$ were affected by dietary treatments $(\mathrm{P}>0.05)$. The Moringa oleifera leaf meal in the experimental diets influenced higher white blood cell $(\mathrm{WBC})$ values in blood which differed $(\mathrm{P}<0.05)$ significantly among the treatment groups. The white blood cell differentials (lymphocyte neutrophil and eosinophil) values were not affected $(\mathrm{P}>0.05)$ by the treatment diets, but the lymphocyte concentration generally tended to be higher than any other leukocyte in the treatment groups.

\section{DISCUSSIONS}

\section{Proximate composition}

The proximate values for the Moringa oleifera leaf meal (MOLM) were similar to those reported by Nouala et al. (2006), Asaolu et al. (2010), Asaolu et al. (2011), Aberra (2011), and Tona et al. (2013) for the same forage. The crude protein (CP) value of $23.24 \%$ obtained for MOLM in the present study favourably compared with the values of $23.27 \%$ and 22.2\% reported by Noula et al. (2006) and Asaolu et al. (2010) respectively. However higher values of $26.74 \%$ and 28.8\% were reported by Asaolu et al. (2011) and Aberra (2011) respectively. The differences in the CP values could be due to the age of the plants, the stage of development 
when the leaves were harvested, location, season, soil type the level of dryness of the leaves and processing method used. The analysis for the experimental diets indicated high dry matter, gross energy and high crude protein content to meet the requirement for WAD does. The dry matter content of the test diets (T2, T3 and T4) compared favourably with the control diet (T1). The crude protein, crude fibre and ash content of the test diets were relatively higher than the control diet and the concentration tended to increase with increasing levels of MOLM in the diets; the MOLM inclusions in the test diets could be responsible for the increases in crude protein contents observed. However, the crude protein content of all the diets were higher than $8 \%$ necessary to provide minimum nitrogen required by micro-organisms to support basic rumen activities (Tona et al., 2013). Crude protein and crude fibre content of the treatment diets ranged from 17.07 - 20.20 and $16.83-18.63$, respectively; which compared with the values of $10.10-19.70$ and $16.67-21.50$ reported for $\mathrm{CP}$ and crude fibre (CF) by Alikwe et al. (2011) and Njidda et al. (2010) respectively for WAD goats.

\section{Feed intake and body weight changes}

The average daily feed intake of the animals varied from $448.26-495.19 \mathrm{~g} /$ day for T4 and T1 respectively. Similarly, the average daily dry matter intake varied from 395.14 448.69 for $\mathrm{T} 4$ and $\mathrm{T} 1$ respectively. The animals fed T4 diet were observed to have a higher feed intake as compared to the control. Dry matter intake (DMI) is an important factor in the utilization of feed by ruminants and is a critical determinant of energy intake and performance (Devendra, 1997). The improvement in intake with Moringa oleifera leaf meal supplement is in agreement with results reported by Ahaotu et al. (2013). The significant dry matter intake obtained in the diet containing 15\% MOLM may be due to its higher protein quality, greater palatability and higher protein content of the diet. This is in line with the result obtained by Adegun and Aye (2013) that diet high in protein content increases intake.

The total weight gain values in the experimental animals varied from 4.14 to $2.90 \mathrm{~kg}$ for $\mathrm{T} 4$ and $\mathrm{T} 1$ respectively. The average daily weight gain values for the WAD does varied from $46.00 \mathrm{~g} /$ day to $33.22 \mathrm{~g} /$ day for $\mathrm{T} 4$ and $\mathrm{T} 1$ respectively. The marked variation in weight gain by the animals fed the experimental diets may be attributed to Moringa oleifera leaf meal due to its high nutrient profile and palatability. The superior weight gains exhibited by animals on $\mathrm{T} 4$ over T1 may also be attributed to the high feed intake and feed utilization of the animals on T4 relative to T1 diet, since voluntary feed intake of an animal is directly related to the body weight changes.

The superior feed efficiency of diets T3 and T4 over the other diets is a reflection of the observed higher feed utilization and indeed higher growth rates of does fed the respective diets. The present value however compared favourably with the observations of Ukanwoko et al. (2013) for WAD does. Factors which influence FCR among other include breed, age and sex of animals as well as nutrition and environment.

\section{Haematological profile}

Packed cell volume (PCV) is used as an index of toxicity and its composition varies with breeds (Ahamefule et al., 2005). In the present study, PCV values ranged between $29.50-32.75 \%$ and nevertheless fell within the physiological range of $22-38 \%$ reported by Krammer (2000) for goats. Aikhuomobhogbe and Orheruata (2006) observed that low PCV results in anemia. This is attributed with reduced oxygen carrying-capacity of blood, increased pulse rate and consequently heart failure. PCV values obtained for all treatment groups were within normal range for goats which is an indication that the treatment diets were nourishing and non-toxic and influenced adequate blood supply. The RBC values $(10.60-11.45 \times 106 / \mu l)$ recorded for the WAD does in this study were within the values $(9.2-13.5 \times 106 / \mu \mathrm{l})$ reported by Daramola et al. (2005) for same breed. Red blood cells characterize anaemia and other conditions affecting red blood cells in animals. The present result shows that the diets supported good health status of the goats, and hence the animals were not anaemic. The values obtained for MCV in the present study are also in agreement with the values reported for WAD goats in previous investigation by Njidda et al. (2013). The normal MCV, MCHC and MCH recorded in this study for the WAD does gave a clear indication of the absence of anaemia among the experimental groups.

High WBC count is usually associated with microbial infection or the presence of foreign body or antigen in the circulating medium (Ahamefule et al., 2005). Daramola et al. (2005) reported a normal range of $6.8-20.1 \times 103 / \mu l$ for WAD goats which agree with the findings of this study. The normal values of WBC obtained in this study suggested well developed immune system of the goats in different dietary groups with the lowest and highest concentrations obtained in diets $\mathrm{T} 1$ and $\mathrm{T} 4$, respectively. These results perhaps highlighted the ethno-veterinary properties of Moringa oleifera as reported by Fahey (2005).

\section{CONCLUSION}

Intakes, body weight changes and heamatology all showed improvement when the Panicum maximum diet was supplemented with Moringa oleifera leaf meal diets. Specifically however, the diet containing 15\% MOLM inclusion had the best performance. The rich nitrogen source of MOLM can further be exploited to boost sustenance and production of WAD especially during periods of scarcity when fodder quality and quantity are low. Incorporation of MOLM in goat's diet would provide nourishable supplement all year round for goats. This way more meat will be realized making animal protein available and affordable.

\section{ACKNOWLEDGMENT}

My profound gratitude goes to Professor F. O. Ahamefule for his guidance. My sincere appreciation goes to Prof. G.C. Okeke, Prof. A. H. Akinmutumi, Dr. E. N. Nwachukwu, and Dr. B. E. Obua for their support. Finally my sincere gratitude 
goes to my wife, Mrs. L.C. Jiwuba for her encouragement and moral support.

\section{REFERENCES}

1. Aberra M. Comparative assessment on chemical compositions and feeding values of leaves of Moringa stenopetala and Moringa oleifera using in vitro gas production method. Ethi. J. App Sci Tech 2011: 2: 31-41.

2. Agboola IO. Performance and Heat Index of West African

Dwarf (WAD) Rams Fed with Adansonia digitata Bark (Baobab) as Supplement. Agric Sci 2012;12:245-Ahamefule FO, Elendu C. Intake and digestibility of West African Dwarf bucks fed cassava leaf-maize offal based diets. J Anim Vet Adv 2010; 9:535-539.

3. Ahamefule FO, Ibeawuchi JA, Okoye FC. Blood biochemistry and haematology of West African Dwarf (WAD) bucks fed pigeon pea-cassava peel based diets. J Anim Vet Adv. 2005; 4:1016-1020.

4. Ahaotu EO, Ezeafulukwe CF, Ayo-Enwerem CM, Ekenyem BU. Effects of Enzyme Fortified Raw Moringa Seed (Moringa oleifera) Waste Diets on Nutrient Utilization and Haematological Parameters of Broilers. Inter J. Appl Sci Engr 2013;1:25-30.

5. Aikhuomobhogbe PU, Orheruata AM. Haematology and blood biochemical indices of West African Dwarf goats vaccinated against pestes des petit ruminants (PPR). Afr J. Biotech. 2006;5:743-748.

6. Alikwe PCN, Faremi AY, Fajemisin AN, Akinsoyinu AO. Performances and nitrogen utilization of West African Dwarf goats fed soybean and dried poultry waste- based concentrates as supplements to cynodon nlemfuensis basal diet. J App Sci Environ Sani 2011;6:191-189.

7. AOAC. Association of Official Analytical Chemists: Official Methods of Analysis. 6th Edition. Washington DC, USA, 2000.

8. Asaolu VO, Binuomote RT, Akinlade JA, Oyelami OS, Kolapo KO. Utilization of Moringa oleifera fodder combinations with Leucaena leucocephala and Gliricidia sepium fodders by West African Dwarf goats. Inter'l J. Agric. Res. 2011;6: 607-619.

9. Asaolu VO, Odeyinka SM, Akinbamijo OO, Sodeinde FG. Effects of moringa and bamboo leaves on groundnut hay utilization by West African Dwarf goats. Liv. Res. Rural Dev. 2010; 22.

10. Aye PA, Adegun MK. Chemical composition and some functional properties of Moringa, Leucaena and Gliricidia leaf meals. Agric. Biol. J. N. Am 2013;4:71-77

11. Daramola JO, Adeloye AA, Fatoba TA, Soladoye AO. Haematological and Biochemical parameters of WAD goats. Liv. Res. R. Dev. 2005; 17:45-56

12. Devendra C. Cassava as a feed source for ruminants. Proceedings of Agricultural Conference on cassava as animal feed 1997; $107-119$.

13. Duncan DB. Multiple range test and multiple F-tests. Biometrics 1955; 1: 1-42.

14. Fadiyimu AA, Alokan JA, Fajemisin AN. Digestibility, nitrogen balance and haematological profile of West African dwarf sheep fed dietary levels of Moringa oleifera as supplement to Panicum maximum. J. American Sci. 2011;6: $634-643$.

15. Fahey JW. Moringa oleifera: A Review of the Medical Evidence for Its Nutritional, Therapeutic, and Prophylactic Properties. Part 1. Trees for Life Journal a forum on beneficial trees and plants 2005;1:1-5.

16. Kramer JW. Normal hematology of cattle, sheep and goat. In Schlam's veterinary hematology. Ed 5th , Philadephia, Williams and Wilkins 2000.

17. Makkar HPS, Becker K. Nutritional value and anti-nutritional components of whole and ethanol extracted Moringa oleifera leaves. Anim Feed Sci Tech 1996;63: 211-228.

18. Nehring K, Haelien GWF. Feed evaluation and calculation based on net energy. J Anim Sci. 1973; 36: 949 - 963. 


\section{Vnos krme, spremembe v telesni masi in hematološki profil zahodno afriških pritlikavih koz, krmljenih z različnimi količinami listov moringe (Moringa oleifera) v obroku}

\section{IZVLEČEK}

Cilj raziskave je bil ugotoviti vpliv dodajanja listov moringe (Moringa oleifera; MOL) v krmni obrok zahodnoafriških pritlikavih koz $(\mathrm{n}=36)$ na zauživanje krme, spremembe telesne mase in hematološki profil. V ta namen so bili pripravljeni štirje različni krmni obroki T1 (kontrola, brez MOL), T2 (5\% MOL), T3 (10\% MOL) in T4 (15\% MOL). Pripravljena krma je bila uporabljena za 90-dnevno krmljenje koz, ki so bile naključno razdeljene v štiri poskusne skupine ( 9 živali na skupino). V raziskavi smo spremljali in statistično analizirali povprečni dnevni vnos krme (ADFI), povprečni dnevni prirast (ADWG), konverzijo krme (FCR) in hematološki profil živali. Rezultati so pokazali značilne razlike v ADFI, ADWG in FCR $(p<0,05)$, pri čemer so imele koze skupine T4 največje vrednosti, FCR pa je bil v skupini T4 najnižji. Hematološki parametri PCV (hematokrita), RBC (rdeča krvna telesca), MCV (srednji volumen eritrocita) in WBC (bela krvna telesca) so se prav tako značilno razlikovali med obravnavanji ( $\mathrm{p}<0,05)$. PCV oziroma hematokrita $(29,50-32,75 \%)$ se je izboljšala $(\mathrm{p}<0,05)$ pri 15\% vključitvi MOL. Število levkocitov je bilo pri kozah, krmljenih z MOL, značilno višje in boljše ( $\mathrm{p}<$ $0,05)$ kot v kontrolni skupini. Krmljenje s 15\% MOL v obroku za koze je izboljšalo njihovo rastnost in hematološki profil. Rezultati kažejo, da je za optimalno proizvodnjo zahodno afriških pritlikavih koz priporočljivo v krmni obrok dodajati $15 \%$ moringinih listov.

Ključne besede: spremembe telesne mase, hematologija, Moringa oleifera, zelena krma, zahodnoafriška pritlikava koza, alternativni krmni dodatki 